Economics Development Analysis Journal 7 (2) (2018)

\title{
Determinan Tingkat Kemiskinan di Daerah Istimewa Yogyakarta Tahun 2007 2014
}

\section{Novita Ika Sari ${ }^{\bowtie}$}

Jurusan Ekonomi Pembangunan, Fakultas Ekonomi, Universitas Negeri Semarang

\begin{tabular}{l} 
Info Artikel \\
\hline Sejarah Artikel: \\
Diterima Januari 2018 \\
Disetujui Maret 2018 \\
Dipublikasikan Mei 2018
\end{tabular}

Keywords:

Readiness, Financial

Inclusion, PKH, Emoney

\begin{abstract}
Abstrak
Penelitian ini bertujuan untuk mengetahui dan menganalisis pengaruh pengeluaran pemerintah untuk sektor pendidikan, kesehatan, pekerjaan umum dan pendapatan per kapita terhadap tingkat kemiskinan di Kabupaten/Kota Provinsi Daerah Istimewa Yogyakarta tahun 2007 - 2014. Variabel yang digunakan dalam penelitian ini adalah pengeluaran pemerintah sektor pendidikan, kesehatan, pekerjaan umum dan pendapatan per kapita terhadap tingkat kemiskinan di Kabupaten/Kota Provinsi DI Yogyakarta. Adapun pengaruh variabel independen terhadap variabel dependen dilakukan dengan Uji F dan Uji t dengan tingkat signifikansi $95 \%(\alpha=5 \%)$. Hasil analisis data menunjukkan bahwa variabel pengeluaran pemerintah sektor pendidikan, kesehatan dan pendapatan per kapita berpengaruh negatif dan signifikan terhadap tingkat kemiskinan. Sedangkan pengeluaran pemerintah sektor pekerjaan umum tidak berpengaruh signifikan terhadap tingkat kemiskinan. Secara simultan, semua variabel independen berpengaruh terhadap tingkat kemiskinan. Koefisien determinasi $\mathrm{R}^{2}$ sebesar $97 \%$ menunjukkan variabel independen yang diteliti mampu menjelaskan pengaruhnya sebesar $97 \%$ terhadap variabel dependen, sedangkan sisanya sebesar $3 \%$ dijelaskan oleh variabel lain yang tidak dimasukkan dalam penelitian.
\end{abstract}

\begin{abstract}
This study aims to determine and analyze the effect of government's expenditure on education, health, public works and per capita income to the level of poverty in the District / City of Daerah Istimewa Yogyakarta Province years 2007-2014. Variables used in this research is the government's expenditure on the sector of education, health, public works and per capita income to the level of poverty in the District / City of Daerah Istimewa Yogyakarta Province. As for the influence of the independent variable on the dependent variable is done by $F$ test and test with significance level of $95 \%(\alpha=5 \%)$. The results of data analysis showed that government's expenditure variable education, health and income per capita is negative and have significant effects on poverty levels while government's expenditure for public works does not significantly influence the level of poverty. Simultaneously, all the independent variables affect the level of poverty. The coefficient of determination $R^{2}$ of $97 \%$ shows the independent variables studied were able to explain the effect of $97 \%$ on the dependent variable, while the remaining $3 \%$ is explained by other variables not included in the study.
\end{abstract}

${ }^{\bowtie}$ Alamat korespondensi:
Ruang Jurnal Gedung L FE UNNES, Sekaran Gunungpati
Semarang, 50229, Indonesia
E-mail: novitaikasari0904@gmail.com 2252-6965




\section{PENDAHULUAN}

Kemiskinan merupakan fenomena umum yang terjadi pada banyak negara di dunia dan menjadi masalah sosial yang bersifat global. Kemiskinan dipengaruhi oleh beberapa faktor yang dapat dilihat dari berbagai dimensi, didalamnya antara lain mencakup dimensi rendahnya tingkat pendidikan dan kesehatan, tidak adanya jaminan masa depan, ketidakberdayaan, ketidakmampuan menyalurkan aspirasi dan ketersisihan dalam peranan sosial (Mawardi dan Sudarno, 2003:1). Mengingat kemiskinan sebagai masalah yang bersifat multidimensi karena menyangkut semua aspek kehidupan manusia mulai dari sosial, ekonomi, budaya dan aspek lainnya, maka upaya pengentasan kemiskinan tidak semata-mata menjadi tanggungjawab pemerintah pusat. Dengan diterapkannya desentralisasi fiskal dan otonomi daerah di Indonesia merupakan salah satu instrumen dalam wujud pemberian wewenang kepada pemerintah daerah untuk mengelola berbagai indikator pembangunan yang berdasarkan pada prioritas pembangunan di setiap wilayah. Salah satunya dengan melihat peran desentralisasi fiskal dalam meningkatkan tingkat kesejahteraan masyarakat, khususnya peran kebijakan tersebut dalam menanggulangi angka kemiskinan.

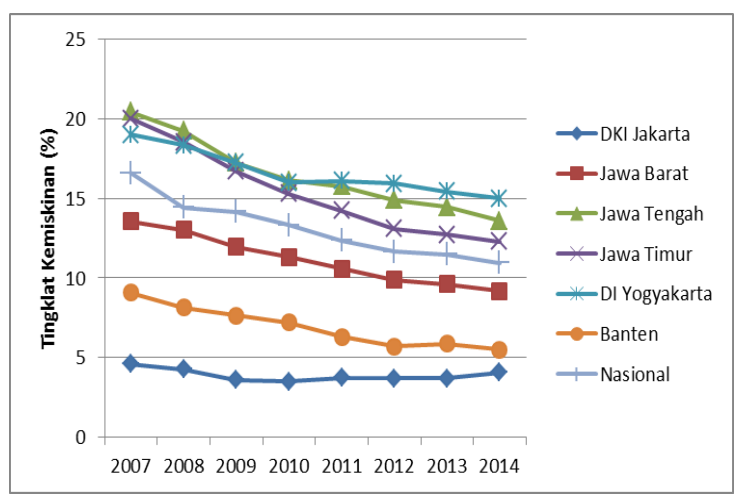

Gambar 1. Perbandingan Tingkat Kemiskinan antar Pulau Jawa dan Nasional Tahun 20072014.

Sumber : BPS Indonesia, 2007-2014

Salah satu Provinsi di Indonesia yang tingkat kemiskinannya cukup tinggi adalah
Provinsi Daerah Istimewa Yogyakarta. Tingkat kemiskinan di Daerah Istimewa Yogyakarta pada tahun 2007-2014 selalu berada diatas persentase tingkat kemiskinan nasional dan masih tingginya angka kemiskinan jika dibandingkan dengan provinsi lain di Pulau Jawa. Secara umum, dalam upaya pengentasan kemiskinan di Provinsi DI Yogyakarta menunjukkan pengaruh yang positif. Hal ini terlihat dari tingkat kemiskinan di Provinsi Daerah Istimewa Yogyakarta yang cenderung mengalami penurunan, akan tetapi angka penurunan kemiskinan relatif lambat rata - rata hanya sebesar $0,57 \%$ per tahun. Tingkat kemiskinan di Provinsi DI Yogyakarta merupakan agregat dari tingkat kemiskinan 5 Kabupaten/Kota di Provinsi DI Yogyakarta. Sebagian besar tingkat kemiskinan di kabupaten/kota provinsi DI Yogyakarta masih relatif tinggi, yaitu masih di atas 10 persen. Hal ini memperlihatkan kemiskinan masih menjadi masalah bagi Provinsi Daerah Istimewa Yogyakarta.

Kemiskinan merupakan sesuatu yang kompleks dalam arti kemiskinan bukan hanya disebabkan karena masalah kekurangan pendapatan dan harta (lack of income and asset), tetapi berkaitan dengan ketidakmampuan untuk mencapai aspek diluar pendapatan (non-income factors) seperti akses layanan publik dan infrastruktur dasar seperti kesehatan, pendidikan, air bersih, dan sanitasi (Bappenas, 2008). Dalam mengimplementasikan kebijakan pemerintah untuk menanggulangi kemiskinan, terlebih dahulu memperhatikan faktor - faktor yang menyebabkan tingkat kemiskinan tersebut. Peran pemerintah dalam mempengaruhi kemiskinan termasuk dalam mengantisipasi kegagalan pasar sangat penting dalam perekonomian. Perannya tersebut melalui kebijakan fiskal. Pemerintah berperan dalam pembentukan modal melalui pengeluaran pemerintah seperti sarana dan prasarana umum yang akan menjadi modal bagi pertumbuhan ekonomi dan akan membantu mengurangi tingkat kemiskinan.

Pengeluaran pemerintah daerah secara nominal selalu meningkat di tiap tahunnya, 
begitu pula pengeluaran pemerintah untuk sektor yang berkaitan langsung dengan kebutuhan untuk mensejahterakan masyarakat.
Pengeluaran tersebut adalah pengeluaran pemerintah di sektor pendidikan, kesehatan dan pekerjaan umum.

Tabel 1. Jumlah Pengeluaran Pembangunan Untuk Sektor Pendidikan, Kesehatan, Pekerjaan Umum di Kabupaten/Kota Provinsi DI Yogyakarta Tahun 2007-2014 (dalam jutaan rupiah)

\begin{tabular}{|c|c|c|c|c|}
\hline \multirow{3}{*}{ Tahun } & \multicolumn{2}{|c|}{ Jenis Pengeluaran } & & \multirow{3}{*}{$\begin{array}{l}\text { Jumlah Total } \\
\text { Pengeluaran } \\
\text { Berdasarkan } \\
\text { Urusan }\end{array}$} \\
\hline & & & & \\
\hline & Pendidikan & Kesehatan & $\begin{array}{l}\text { Pekerjaan } \\
\text { Umum }\end{array}$ & \\
\hline 2007 & 991.270 & 291.162 & 218.774 & 2.790 .224 \\
\hline 2008 & 1.505 .521 & 364.599 & 450.237 & 3.926 .409 \\
\hline 2009 & 1.724 .052 & 400.945 & 273.944 & 3.986 .929 \\
\hline 2010 & 1.814 .036 & 466.757 & 225.866 & 4.164 .059 \\
\hline 2011 & 2.601 .182 & 536.473 & 330.671 & 5.054 .126 \\
\hline 2012 & 2.679 .752 & 618.060 & 398.373 & 5.483 .117 \\
\hline 2013 & 2.945 .485 & 769.214 & 541.465 & 6.395 .373 \\
\hline 2014 & 3.254 .540 & 970.953 & 799.191 & 7.567 .678 \\
\hline
\end{tabular}

Sumber : Direktorat Jenderal Perimbangan Keuangan, 2007-2014

Anggaran sektor pendidikan pada tahun 2007 sebesar Rp. 991.270 juta dan terus meningkat secara signifikan pada tahun 2014 menjadi Rp. 3.254.540 juta. Begitu juga anggaran sektor kesehatan di tahun 2007 sebesar Rp. 291.162 juta dan terus mengalami kenaikan yang signifikan di tahun 2014 sebsar Rp. 970.953 juta, dan anggaran sektor pekerjaan umum di tahun 2007 sebesar Rp. 218.774 juta meningkat secara signifikan di tahun 2014 sebesar Rp. 799.191 juta. Selain itu, indikator tingkat kesejahteraan penduduk suatu wilayah adalah dengan melihat angka PDRB per kapita. Pendapatan per kapita sering digunakan sebagai indikator pembangunan.

Pendapatan per kapita serta Pengeluaran pemerintah dalam berbagai sektor yang tercantum pada pengeluaran menurut urusan terus meningkat secara signifikan dari tahun 2007 sampai 2014. Pendapatan per kapita dan Pengeluaran pemerintah yang terus meningkat tersebut tidak disertai dengan percepatan penurunan tingkat kemiskinan di wilayah Kabupaten/Kota Provinsi DI Yogyakarta.

Menurut Rostow dan Musgrave dalam Mangkoesobroto (1995:170) yang menghubungkan perkembangan pengeluaran pemerintah dengan tahap-tahap pembangunan ekonomi yang dibedakan antara tahap awal, tahap menengah dan tahap lanjut. Pada tahap awal terjadinya perkembangan ekonomi, persentase investasi pemerintah terhadap total investasi besar karena pemerintah harus menyediakan fasilitas dan pelayanan seperti pendidikan, kesehatan, transportasi dan sebagainya. Kemudian pada tahap menengah terjadinya pembangunan ekonomi, investasi pemerintah masih diperlukan untuk meningkatkan pertumbuhan ekonomi agar dapat semakin meningkat, tetapi pada tahap ini peranan investasi swasta juga semakin besar. Peranan pemerintah tetap besar pada tahap menengah, oleh karena itu peranan swasta yang semakin besar banyak menimbulkan kegagalan pasar, dan juga menyebabkan pemerintah harus menyediakan barang dan jasa publik dalam jumlah yang lebih banyak dan kualitas yang lebih baik. Selain itu, menurut Nurkse dalam Suryana (2000:45) kemiskinan suatu wilayah bermuara pada teori lingkaran setan kemiskinan dari sisi penawaran (Supply), tingkat pendapatan masyarakat yang rendah yang diakibatkan oeh tingkat produktivitas yang rendah menyebabkan kamampuan masyarakat untuk menabung rendah. Kemampuan untuk menabung yang rendah menyebabkan tingkat pembentukan, 
modal rendah, tingkat pembentukan modal (Investasi) yang rendah menyebabkan kekurangan modal, dan dengan demikian tingkat produktivitas juga rendah dan seterusnya.

Beberapa penelitian terdahulu yang meneliti mengenai pengaruh pengeluaran pemerintah dan pendapatan perkapita terhadap tingkat kemiskinan dilakukan oleh Wibowo (2014), Rahim (2014), Widodo dkk (2011), Kifli (2007), Khasanah (2016) dan Birowo (2011).

Wibowo lebih fokus meneliti tentang pengeluaran pemerintah saja diantaranya pengeluaran pemerintah sektor pertanian, pendidikan, kesehatan dan infrastruktur di Jawa Tengah. Sedangkan, Rahim (2014), Kifli (2011) dan Khasanah (2016) menggunakan variabel yang berbeda dengan penelitian ini serta Widodo dkk (2011) dan Birowo (2011) menggunakan alat analisis lain seperti analisis regresi berganda (Multiple Regression Analysis) dan OLS (Ordinary Least Square).

\section{METODE PENELITIAN}

Jenis penelitian yang digunakan dalam penelitian ini adalah penelitian kuantitatif. Pada penelitian ini, jenis data yang digunakan adalah data sekunder. Sedangkan menurut waktu pengumpulannya, jenis data dalam penelitian ini adalah data panel (gabungan time series dan cross section) dalam kurun waktu 2007 sampai 2014.

Sumber data diperoleh dari Badan Pusat Statistik (BPS) Provinsi DI Yogyakarta dan situs resmi Direktorat Jenderal Perimbangan Keuangan Republik Indonesia. Teknik analisis data yang digunakan adalah deskriptif kuantitatif dan analisis statistik. Analisis statistik meliputi regresi data panel (uji Chow dan uji Hausman), uji asumsi klasik (uji normalitas, uji multikolinearitas, uji heteroskedastisitas, uji autokorelasi), uji hipotesis (uji $\mathrm{F}$ dan uji $\mathrm{t}$ ), koefisien determinasi.

Berdasarkan observasi data yang dilakukan dan simulasi terhadap hasil regresi maka diputuskan model persamaan yang digunakan adalah sebagai berikut: $\mathrm{YKM}=\mathrm{f}($ Xspend, Xskes, Xspu, XPDRBK)
Model Persamaan :

KMit $=\beta 0+\beta 1 \log$ SPENDit $+\beta 2 \operatorname{logSKESit}+$ $\beta 3 \log$ SPUit $+\beta 4 \log$ PDRBKit $+\mu$ it

Dimana:

KM : Persentase penduduk miskin

$\operatorname{logSPEND} \quad$ : Pengeluaran pemerintah sektor pendidikan

$\operatorname{logSKES} \quad$ : Pengeluaran pemerintah sektor kesehatan

$\operatorname{logSPU} \quad$ : Pengeluaran pemerintah sektor pekerjaan umum

$\log$ PDRBK $\quad$ : PDRB per kapita

$\beta 0 \quad$ : Intersep

$\beta 1, \beta 2, \beta 3 \quad$ : Koefisien regresi

$\quad \mu$ it $\quad:$ Komponen error di waktu $t$ untuk unit cross section $i$

i $\quad: 1,2, \ldots, 5$

t $: 2007-2014$

Adapun alasan penggunaan model logaritma (log) dalam persamaan yang dirumuskan diatas adalah untuk mendekatkan skala data dan karena adanya perbedaan satuan (pengeluaran pemerintah menggunakan satuan jutaan rupiah, sementara indikator kemiskinan menggunakan satuan persen)

Model yang digunakan untuk melihat pengaruh pengeluaran pemerintah sektor pendidikan (SPEND), sektor kesehatan (SKES), sektor pekerjaan umum (SPU) dan pendapatan per kapita (PDRBK) terhadap tingkat kemiskinan (KM) adalah untuk pemilihan model regresi data panel (Common Effect Model atau Fixed Effect Model) yang sesuai pendugaan digunakan uji Chow. Nilai signifikansi dilihat dari nilai probabilitas (F-Statistik) sebesar 0,0000 $<0,05$ sehingga $\mathrm{H}_{0}$ ditolak maka dapat disimpulkan model data panel yang digunakan untuk menghasilkan estimasi paling baik dalam mengestimasi pengaruh pengeluaran pemerintah sektor pendidikan, kesehatan, pekerjaan umum dan pendapatan per kapita terhadap tingkat kemiskinan di Kabupaten/Kota Provinsi DI Yogyakarta 2007-2014 adalah model fixed effect. Selanjutnya akan dilakukan pengujian untuk memilih model terbaik diantara fixed effect dan random effect menggunakan uji Hausman. 
Tabel 2. Hasil Uji Chow

\begin{tabular}{llll}
\hline Uji Pengaruh & Nilai Statistik & d.f. & Probabilitas \\
\hline Cross-section $F$ & 35,328749 & 4,31 & 0,0000 \\
Cross-section Chi-square & 68,613478 & 4 & 0,0000
\end{tabular}

Taraf signifikansi : $\alpha=5 \%$

Sumber : data diolah (eviews 9), 2016

Tabel 3. Hasil Uji Hausman

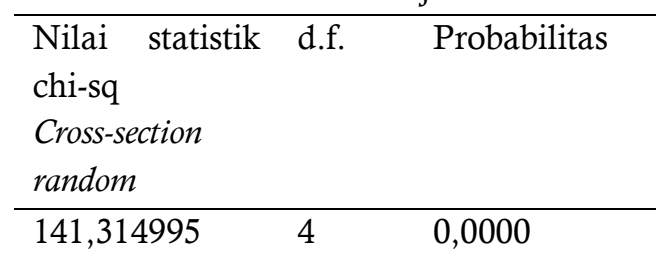

Tingkat signifikansi : $\alpha=5 \%$

Sumber : data diolah (eviews 9), 2016
Nilai signifikansi dilihat dari nilai probabilitas (Chi-Square) sebesar 0,0000 $<0,05$ sehingga $\mathrm{H} 0$ ditolak yang berarti menolak model random effect. Sehingga kesimpulannya adalah menolak $\mathrm{H} 0$ yang menyatakan model fixed effect lebih baik digunakan dalam penelitian ini daripada model random effect.

Dari pemilihan model yang sudah dilakukan, diperoleh model regresi data panel sebagai berikut :

$$
\begin{aligned}
K M_{i t}= & 139,5678-1,218211 \log S P E N D_{i t}-0,867561 \log S K E S_{i t}+0,920926 \log S P U_{i t} \\
& -5,847739 \log P D R B K_{i t}+\mu_{i t}
\end{aligned}
$$

t statistik $\quad(4,861786)(-2,849057)$

$(-2,084693)(1,668074)(-2,397488)$

Berdasarkan hasil uji normalitas nilai statistik uji Jarque - Bera sebesar 3,703912< $\chi_{(4: 5 \%)}^{2}$ sebesar 9,488 sehingga menolak $H_{0}$, maka dapat disimpulkan bahwa residual berdistribusi normal. Hasil Uji Multikolinearitas antara variabel independen menunjukkan bahwa nilai R2 regresi utama sebesar 0,974563 > R2 regresi parsial (auxiliary regression) yang dilambangkan R2, R3, R4 dan R5, dengan masing masing nilainya sebesar R2 (0,719995), R3 $(0,715851), \mathrm{R} 4(0,718674)$ dan R5 $(0,960633)$ maka dapat dikatakan bahwa dalam model penelitian ini tidak terdapat masalah multikolinearitas.

Pada penelitian ini menggunakan metode GLS (Generalized Least - Square) yang pada intinya memberikan pembobotan pada variasi data yang digunakan, yaitu dengan kuadrat varians dari model. Sehingga dapat dikatakan dengan menggunakan metode GLS (Generalized Least - Square) masalah heteroskedastisitas sudah dapat teratasi (Gujarati, 2011:476).

Deteksi autokorelasi yang digunakan dalam penelitian ini adalah dengan cara uji
Durbin Watson. Pada output terlihat bahwa nilai DW - stat bernilai 1,621860 berada pada kisaran angka $1(\mathrm{dL} \leq \mathrm{DW}-$ stat $\leq \mathrm{du})$ yaitu $(1,285 \leq$ $1,621 \leq 1,721)$. Hal ini mengindikasikan bahwa pada model tersebut tidak dapat mengambil kesimpulan apapun.

Selanjutnya, sesuai dengan yang dikatakan oleh Gujarati di dalam bukunya, bila menggunakan model GLS (Generalized Least Square) dalam penelitian maka hasil output tidak memiliki masalah dalam autokorelasi (Gujarati, 2011: 43). Dari hasil regresi pengaruh pengeluaran pemerintah sektor pendidikan (SPEND), pengeluaran pemerintah sektor kesehatan (SKES). Pengeluaran pemerintah sektor pekerjaan umum (SPU) dan pendapatan per kapita (PDRBK) terhadap tingkat kemiskinan di Kabupaten/Kota Provinsi DI Yogyakarta tahun 2007 - 2014, diperoleh nilai R2 dengan pendekatan fixed effect cross section weight sebesar $97,45 \%$ dapat dijelaskan oleh variasi 4 variabel independen, sedangkan sisanya sebesar 2,55\% dijelaskan oleh variabel lain diluar model.

Nilai statistik uji $\mathrm{F}$ sebesar 148.4630 $>F_{(4 ; 35 ; 5 \%)}$ sebesar 2,64 sehingga menolak $H_{0}$, 
yang berarti variabel independen yaitu Variabel Pengeluaran pemerintah sektor pendidikan, kesehatan, pekerjaan umum dan pendapatan per kapita secara serentak atau bersama - sama mempengaruhi variabel tingkat kemiskinan di Kabupaten/Kota Provinsi DI Yogyakarta tahun 2007 - 2014.

Variabel Pengeluaran Pemerintah Sektor Pendidikan memiliki $\mathrm{p}$ - value $\mathrm{t}$ - stat 0,0077 . Karena nilai tersebut $<0,05$ maka variabel ini berada pada daerah tolak H0. Sehingga dapat diambil kesimpulan bahwa variabel Pengeluaran Pemerintah Sektor Pendidikan merupakan variabel yang mempengaruhi Tingkat Kemiskinan 5 Kabupaten dan Kota di Provinsi DI Yogyakarta.

Variabel Pengeluaran Pemerintah Sektor Kesehatan memiliki $\mathrm{p}$ - value $\mathrm{t}$ - stat 0,0454 . Karena nilai tersebut $<0,05$ maka variabel ini berada pada daerah tolak H0. Sehingga dapat diambil kesimpulan bahwa variabel Pengeluaran Pemerintah Sektor Kesehatan merupakan variabel yang mempengaruhi Tingkat Kemiskinan 5 Kabupaten dan Kota di Provinsi DI Yogyakarta.

Variabel Pengeluaran Pemerintah Sektor Pekerjaan Umum memiliki $\mathrm{p}$ - value $\mathrm{t}$ - stat 0,1054 . Karena nilai tersebut $>0,05$ maka variabel ini berada pada daerah terima $\mathrm{H} 0$. Sehingga dapat diambil kesimpulan bahwa variabel Pengeluaran Pemerintah Sektor Pekerjaan Umum merupakan variabel yang tidak mempengaruhi Tingkat Kemiskinan 5 Kabupaten dan Kota di Provinsi DI Yogyakarta.

Variabel Pendapatan Per Kapita memiliki $\mathrm{p}$ - value $\mathrm{t}$ - stat 0,0227. Karena nilai tersebut $<$ 0,05 maka variabel ini berada pada daerah tolak H0. Sehingga dapat diambil kesimpulan bahwa variabel Pendapatan Per Kapita merupakan variabel yang mempengaruhi Tingkat Kemiskinan 5 Kabupaten dan Kota di Provinsi DI Yogyakarta.

\section{HASIL DAN PEMBAHASAN}

Pengeluaran pemerintah sektor pendidikan memberikan pengaruh negatif dan signifikan terhadap tingkat kemiskinan dengan nilai

koefisien

sebesar

-1,218211. Artinya setiap setiap terjadi peningkatan pengeluaran pemerintah untuk sektor pendidikan sebesar 1 persen maka akan mengakibatkan penurunan tingkat kemiskinan sebesar 1,218211 persen dengan asumsi cateris paribus. Penelitian didukung oleh penelitian sebelumnya yang dilakukan oleh Wibowo (2014) menyatakan bahwa peningkatan pengeluaran sektor pendidikan berpengaruh negatif terhadap tingkat kemiskinan.

Hasil penelitian ini sesuai dengan teori model pembangunan tentang perkembangan pengeluaran pemerintah yang dikembangkan oleh Rostow dan Musgrave yang menghubungkan perkembangan pengeluaran pemerintah dengan tahap-tahap pembangunan ekonomi yang dibedakan antara tahap awal, tahap menengah dan tahap lanjut. Pada tahap awal terjadinya perkembangan ekonomi, persentase investasi pemerintah terhadap total investasi besar karena pemerintah harus menyediakan fasilitas dan pelayanan seperti pendidikan, kesehatan, transportasi dan sebagainya. Kemudian pada tahap menengah terjadinya pembangunan ekonomi, investasi pemerintah masih diperlukan untuk meningkatkan pertumbuhan ekonomi agar dapat semakin meningkat, tetapi pada tahap ini peranan investasi swasta juga semakin besar. Peranan pemerintah tetap besar pada tahap menengah, oleh karena itu peranan swasta yang semakin besar banyak menimbulkan kegagalan pasar, dan juga menyebabkan pemerintah harus menyediakan barang dan jasa publik dalam jumlah yang lebih banyak dan kualitas yang lebih baik. Pengaruh Pengeluaran Pemerintah Sektor Kesehatan terhadap Tingkat Kemiskinan, pengeluaran pemerintah sektor kesehatan memberikan pengaruh negatif dan signifikan terhadap tingkat kemiskinan dengan nilai koefisien sebesar $-0,867561$.

Hasil penelitian ini sesuai dengan hipotesis yang menyatakan pengeluaran pemerintah sektor kesehatan berpengaruh terhadap tingkat kemiskinan. Artinya setiap setiap terjadi peningkatan pengeluaran pemerintah untuk sektor kesehatan sebesar 1 
persen maka akan mengakibatkan penurunan tingkat kemiskinan sebesar 0,867561 persen dengan asumsi cateris paribus. Hasil ini juga didukung oleh penelitian yang dilakukan Wahyudi (2011) yang menyatakan bahwa alokasi belanja daerah untuk urusan kesehatan memiliki pengaruh yang signifikan dalam mengurangi kemiskinan di Kabupaten/Kota Provinsi Jawa Tengah. Selain itu, penelitian yang dilakukan oleh Khasanah (2016) menyatakan bahwa pengeluaran pemerintah fungsi kesehatan memberikan pengaruh negatif dan signifikan terhadap jumlah penduduk miskin.

Pengaruh Pengeluaran Pemerintah Sektor Pekerjaan Umum terhadap Tingkat Kemiskinan, dari hasil penelitian menunjukkan bahwa pengeluaran pemerintah sektor pekerjaan umum tidak berpengaruh signifikan terhadap tingkat kemiskinan dengan nilai koefisien positif sebesar 0,920926. Artinya setiap terjadi peningkatan pengeluaran pemerintah untuk sektor pekerjaan umum sebesar 1 persen maka akan mengakibatkan peningkatan tingkat kemiskinan sebesar 0,920926 persen dengan asumsi cateris paribus.

Hasil ini sesuai dengan penelitian yang dilakukan oleh Santoso (2011) menyatakan bahwa alokasi belanja daerah bidang pekerjaan umum tidak berpengaruh terhadap indeks kemiskinan di Jawa Timur. Penelitian yang dilakukan oleh Triyowati (2005) juga menyatakan bahwa peningkatan pengeluaran di sektor infrastruktur tidak mempunyai dampak terhadap kemiskinan. Dapat dilihat bahwa pengeluaran pemerintah sektor pekerjaan umum tidak berpengaruh signifikan terhadap tingkat kemiskinan. Hal ini kemungkinan disebabkan karena pembangunan infrastruktur dinilai tidak berdampak terhadap masyarakat miskin. Selain itu, pembangunan hanya terpusat pada daerah yang memiliki infrastruktur yang baik saja, yaitu di daerah perkotaan, kabupaten atau tempat yang dianggap strategis. Sedangkan, fokus pembangunan belum menyentuh ke pelosok desa. Padahal sebagian besar penduduk miskin lebih banyak bermukim di daerah pelosok desa.

Pengaruh Pendapatan Per Kapita terhadap Tingkat Kemiskinan, variabel pendapatan per kapita memberikan pengaruh negatif dan signifikan terhadap tingkat kemiskinan dengan nilai koefisien sebesar 5.847739. Hasil penelitian ini sesuai dengan hipotesis yang menyatakan pendapatan per kapita berpengaruh terhadap tingkat kemiskinan. Artinya setiap setiap terjadi peningkatan pendapatan per kapita sebesar 1 persen maka akan mengakibatkan penurunan tingkat kemiskinan sebesar 5.847739 persen dengan asumsi cateris paribus.

Hasil penelitian ini sesuai dengan teori lingkaran setan kemiskinan Nurkse, yang menyatakan kemiskinan suatu wilayah bermuara pada teori lingkaran setan kemiskinan dari segi penawaran (Supply), tingkat pendapatan masyarakat yang rendah yang diakibatkan oeh tingkat produktivitas yang rendah menyebabkan kamampuan masyarakat untuk menabung rendah. Kemampuan untuk menabung yang rendah menyebabkan tingkat pembentukan, modal rendah, tingkat pembentukan modal (Investasi) yang rendah menyebabkan kekurangan modal, dan dengan demikian tingkat produktivitas juga rendah dan seterusnya.

Peningkatan pendapatan per kapita merupakan keberhasilan pemerintah dalam upaya membangun daerah dan mengurangi kemiskinan di Provinsi DI Yogyakarta. Tingkat kemiskinan di Kabupaten/Kota Provinsi DI Yogyakarta dalam periode 8 tahun terakhir cenderung menurun yang dipengaruhi oleh peningkatan nilai pendapatan per kapita dari tahun ke tahun. Peningkatan pendapatan per kapita ini meningkatkan kemampuan konsumsi masyarakat ke dalam tahap masyarakat sejahtera yang mampu memenuhi kebutuhan pokok. Ketika kebutuhan pokok setiap individu masyarakat dapat terpenuhi artinya masyarakat

tersebut tidak termasuk dalam kategori penduduk miskin.

\section{SIMPULAN}

Berdasarkan hasil analisis pengaruh pengeluaran pemerintah sektor pendidikan, pengeluaran pemerintah sektor kesehatan, pengeluaran pemerintah sektor pekerjaan umum 
dan pendapatan per kapita terhadap tingkat kemiskinan di Kabupaten/Kota Provinsi DI Yogyakarta tahun 2007 - 2014 dapat diambil kesimpulan bahwa variabel pengeluaran pemerintah sektor pendidikan berpengaruh negatif dan signifikan dengan taraf signifikansi 5\% terhadap tingkat kemiskinan di Kabupaten/Kota Provinsi DI Yogyakarta tahun 2007 - 2014, variabel pengeluaran pemerintah sektor kesehatan berpengaruh negatif dan signifikan dengan taraf signifikansi 5\% terhadap tingkat kemiskinan di Kabupaten/Kota Provinsi DI Yogyakarta tahun 2007 - 2014, variabel pengeluaran pemerintah sektor pekerjaan umum tidak berpengaruh signifikan dengan taraf signifikansi $5 \%$ terhadap tingkat kemiskinan di Kabupaten/Kota Provinsi DI Yogyakarta tahun 2007 - 2014, variabel Pendapatan Per kapita berpengaruh negatif dan signifikan dengan taraf signifikansi $5 \%$ terhadap tingkat kemiskinan di Kabupaten/Kota Provinsi DI Yogyakarta tahun 2007 - 2014, variabel pengeluaran pemerintah sektor pendidikan, kesehatan, pekerjaan umum dan pendapatan per kapita secara bersama-sama berpengaruh signifikan terhadap tingkat kemiskinan di Kabupaten/Kota Provinsi DI Yogyakarta tahun 2007 - 2014.

Berdasarkan hasil analisis dan pembahasan diatas, saran yang dapat diberikan kepada pihak yang bersangkutan sebaiknya Pemerintah daerah perlu terus meningkatkan kualitas sumber daya manusia (SDM) melalui pendidikan berkelanjutan baik dalam jenis maupun jenjang pendidikan guna menghadapi persaingan yang semakin ketat dalam dunia kerja, serta memperluas akses terhadap pendidikan khususnya di SMK sesuai kebutuhan dan keunggulan lokal dengan menambah

program pendidikan kejuruan yang sesuai dengan tuntutan pasar kerja yang berkembang, dan untuk SMA perlu penambahan pendidikan keterampilan bagi siswa yang akan bekerja setalah lulus sehingga dapat memutuskan rantai kemiskinan. Selain itu, dalam pemberian subsidi pendidikan yang berupa beasiswa bagi masyarakat miskin, para pengambil kebijakan perlu melakukan monitoring dan evaluasi secara langsung agar pemberian subsidi tersebut lebih tepat sasaran, kebijakan pemerintah daerah dalam alokasi anggaran sektor kesehatan perlu ditingkatkan khususnya untuk peningkatan kualitas layanan kesehatan. Peningkatan kualitas layanan kesehatan antara lain subsidi kesehatan untuk penyakit berat, penyakit yang membutuhkan tindakan operasi, persalinan baik normal maupun yang memerlukan tindakan lain. Selain itu, perlunya peningkatan kesehatan masyarakat melalui penyuluhan akan pentingnya kesehatan dan diadakanya program pengobatan murah bahkan gratis untuk masyarakat tidak mampu, pemerintah daerah dalam mengalokasikan belanja publik di sektor pekerjaan umum (PU), seharusnya mengutamakan manfaat dan dampaknya bagi kesejahteraan masyarakat miskin dan tidak sekedar peningkatan alokasi untuk pelayanan publik. Selain itu, Pemerintah daerah hendaknya memiliki komitmen dalam usaha menurunkan tingkat kemiskinan melalui kebijakan terkait dengan pembangunan sektor pekerjaan umum yang berpihak pada masyarakat miskin, kebijakan pemerintah daerah diharapkan mampu memberikan ruang gerak yang leluasa bagi pelaku ekonomi di daerah, , sehingga efek yang ditimbulkan dapat mendorong dan meningkatkan kemampuan ekonomi masyarakat miskin serta meningkatkan pertumbuhan ekonomi daerah. Dengan demikian strategi pembangunan ke depan harus diupayakan untuk menciptakan dan menggali potensi-potensi ekonomi daerah sehingga pertumbuhan yang terjadi akan menghasilkan pendapatan per kapita yang merata dan manfaat besar dalam menurunkan tingkat kemiskinan.

\section{DAFTAR PUSTAKA}

Badan Pusat Statistik. 2007-2014. DIY Dalam Angka 2007-2014. Yogyakarta : BPS Provinsi DI Yogyakarta.

Badan Pusat Statistik. 2007-2014. Statistik Indonesia 2007-2014. BPS Indonesia.

Birowo, Tejo. 2011. Relationship Between Government Expenditure And Poverty Rate In 
Indonesia (Comparison of Budget

Clasifications Before And After Budget Management Reform in 2004). Graduate

School of Asia Pasific Studies Risumeikanasia Pasific University Japan.

DJPKD (Direktorat Jenderal Perimbangan Keuangan Daerah), berbagai tahun. Data pengeluaran pemeritah menurut Urusan.

-----2007 - 2014. Data Pengeluaran Pemerintah Urusan pendidikan, urusan kesehatan, dan urusan pekerjaan umum.

Gujarati, Damodar dan Porter, Dawn. 2011-2012. Dasar-Dasar Ekonometrika Buku 1, Edisi 5. Jakarta : Salemba Empat.

Khasanah, Miftakhul. 2016. Pengaruh Pengeluaran Pemerintah untuk Fungsi Kesehatan, Pendidikan, Perumahan dan Fasilitas Umum Terhadap Jumlah Penduduk Miskin di Indonesia Tahun 2008-2013. Economics Development Analysis Journal. Vol 5, No.1 Hal: 1-8. Semarang : FE UNNES.

Kifli, Sofia, 2007. "Faktor-Faktor Yang Mempengaruhi Kemiskinan di Provinsi Lampung, 2000-2005". Tesis S2. Yogyakarta : Sekolah Pascasarjana UGM.

Mangkoesoebroto, Guritno. 1995. Ekonomi Publik. Edisi Ketiga. Yogyakarta : BPFE.

Mawardi, Sulton. Sumarto, Sudarno. 2003. Kebijakan Publik Yang Memihak Orang Miskin (Fokus: Pro-Poor Budgeting). SMERU Bahan Pelatihan.

Rahim, Asri, 2014. "Pengaruh PNPM Mandiri Pedesaan, Pengeluaran Pemerintah Belanja Modal) dan PDRB Terhadap Tingkat Kemiskinan di Provinsi Maluku Tahun 20082012". Tesis S2. Yogyakarta : Sekolah Pascasarjana UGM.

Suryana. 2000. Ekonomi Pembangunan : Problematika dan Pendekatan. Jakarta : Salemba Empat.

Santoso, Adi Lukman. 2011. Pengaruh PNPM dan Alokasi Belanja Daerah untuk Pendidikan, Kesehatan, dan Pekerjaan Umum terhadap Penanggulangan Kemiskinan (Studi Kasus Kabupaten/Kota di Provinsi Jawa Timur Tahun 2007-2009). Tesis S2. Jakarta : Universitas Indonesia.

Triyowati, Hermien. 2004. Dampak Desentralisasi Fiskal terhadap Penyerapan Tenaga Kerja dan Tingkat Kemiskinan. Media Ekonomi, Vol. XI no. 3 Hal: 201-218. Jakarta: FE Trisakti.

Undang-Undang No. 32 Tahun 2004 tentang Pemerintahan Daerah.
Undang-Undang No. 33 Tahun 2004 tentang Perimbangan Keuangan Antara Pusat dan Pemerintah Daerah.

Wahyudi. 2011. Pengaruh Alokasi Belanja Daerah Untuk Urusan Pendidikan, Kesehatan, dan Pekerjaan Umum Terhadap Penanggulangan Kemiskinan (Studi Kasus Kabupaten/Kota Di Provinsi Jawa Tengah Tahun 2007-2009). Tesis S2. Jakarta : Universitas Indonesia.

Wibowo, Mohamad Erhan. 2014. Analisis Pengaruh Pengeluaran Pemerintah di Sektor Pertanian, Pendidikan, Kesehatan dan Infrastruktur Terhadap Tingkat Kemiskinan (Studi Kasus di Kabupaten/Kota Provinsi Jawa Tengah). Journal Of Economics. Vol 3, No $4 \mathrm{Hal}$ : 1-9. Semarang : Universitas Diponegoro.

Widodo, Adi, Dkk. 2011. Analisis Pengaruh Pengeluaran Pemerintah di Sektor Pendidikan dan Kesehatan Terhadap Pengentasan Kemiskinan Melalui Peningkatan Pembangunan Manusia di Provinsi Jawa Tengah. Jurnal Dinamika Ekonomi Pembangunan. Vol. 1 no. $1 \mathrm{Hal}$ : $25-42$. Semarang : Universitas Diponegoro. 